\title{
A solid-polymer-electrolyte direct methanol fuel cell (DMFC) with Pt-Ru nanoparticles supported onto poly(3,4-ethylenedioxythiophene) and polystyrene sulphonic acid polymer composite as anode
}

\author{
K K TINTULA ${ }^{\mathrm{a}}$, S PITCHUMANI ${ }^{\mathrm{a}}$, P SRIDHAR ${ }^{\mathrm{a}}$ and A K SHUKLA ${ }^{\mathrm{b}, *}$ \\ ${ }^{a}$ Central Electrochemical Research Institute (CSIR), Madras Unit, Chennai 600113 \\ ${ }^{\mathrm{b}}$ Solid State and Structural Chemistry Unit, Indian Institute of Science, Bangalore 560012 \\ e-mail: shukla@sscu.iisc.ernet.in
}

MS received 8 December 2009; revised 19 February 2010; accepted 23 February 2010

\begin{abstract}
Nano-sized Pt-Ru supported onto a mixed-conducting polymer composite comprising poly(3,4-ethylenedioxythiophene)-polystyrene sulphonic acid (PEDOT-PSSA) is employed as anode in a solid-polymer-electrolyte direct methanol fuel cell (SPE-DMFC) and its performance compared with the SPE-DMFC employing conventional Vulcan XC-72R carbon supported Pt-Ru anode. Physical characterization of the catalyst is conducted by Fourier-transform infra-red (FTIR) spectroscopy, X-ray diffraction (XRD), Scanning electron microscopy (SEM) and Energy dispersive X-ray analysis (EDAX) in conjunction with cyclic voltammetry and chronoamperometry. The study suggests that PEDOT-PSSA to be a promising alternative catalyst-support-material for SPE-DMFCs.
\end{abstract}

Keywords. Poly(3,4-ethylenedioxythiophene) and poly (styrene sulphonic acid); catalyst support; DMFC; corrosion.

\section{Introduction}

The direct use of methanol in a fuel cell clearly offers considerable attractions from the point of view of simplicity of design and hence, potentially, of cost. ${ }^{1-3}$ In essence, a solid-polymer-electrolyte direct methanol fuel cell comprises an anode at which methanol is electrochemically oxidized to carbon-di-oxide, a cathode at which oxygen is reduced to water and a Nafion membrane that acts as electrolyte. One of the main drawbacks of the solidpolymer-electrolyte direct methanol fuel cells (SPEDMFCs) is the sluggish anode reaction, which, coupled with the inefficient cathode reaction gives rise to low overall cell performance. ${ }^{4-10}$

As revealed in the literature, several efforts have been made to enhance the electro-oxidation of methanol by tailoring the carbon-supported $\mathrm{Pt}-\mathrm{Ru}$ catalyst. ${ }^{11,12}$ But the choice of a suitable carbon support still remains a factor as it affects the performance of supported catalyst through interactions between the catalyst and the support that modify the catalyst activity. ${ }^{13-15}$ These interactions are particu-

*For correspondence larly dependent on the nature of the functional groups on the support. For instance, it is found that carbons with lower concentration of acid-base groups $^{13}$ and carbons with sulfur- or nitrogen-based functionalities ${ }^{15}$ ameliorate the catalytic activity. Consequently, considerable efforts have been expended on the optimization and development of new support material such as graphite nanofibres, ${ }^{16}$ carbon nanotubes ${ }^{17,18}$ and mesocarbon microbeads ${ }^{19}$ in order to improve both the oxidation rate and electrode stability towards methanol electro-oxidation. These materials have high surface-area that facilitates uniform dispersion of catalyst and, since these are electronically more conductive than carbon, these have also attracted attention as alternate support materials for fuel cell catalysts.

Conducting polymers due to their high electronic conductivity $\left(10^{-6}-10^{3} \mathrm{~S} / \mathrm{cm}\right)$, high stability and high surface-area have found wide applications in sensors, electrochemical actuators, electromagnetic shielding, corrosion inhibitors, and polymeric batteries. ${ }^{20-23}$ The most common conducting polymers, such as polyaniline (PAni), polypyrrole (PPy), polythiophene (PTh) and their derivatives, used as fuel-cell-catalyst supports are conjugated polymers 
with heteroatoms in the main chain. ${ }^{24-30}$ These polymers are especially attractive since their electronic conductivity values are about one to two orders higher than the carbon particles. ${ }^{31}$ Of the entire conducting polymers, poly (3,4-ethylenedioxythiophene) (PEDOT), modified PTh, appears to be the most adequate support for fuel-cell catalysts. PEDOT is known to be stable with its electronic conductivity values ranging between $1-100 \mathrm{~S} / \mathrm{cm}$ based on the dopant used, ${ }^{32}$ it can also be doped with ionically-conducting polymers, such as polystyrene sulphonic acid (PSSA), to make it mixed (electronic + ionic) conducting. Drillet et $a l^{33}$ were the first to demonstrate PEDOT-supported Pt as the anode for DMFCs; these authors observed a striking change in the morphology after prolonged storing of PEDOT reaction-layer in air and reported ameliorated performance in relation to freshlyprepared PEDOT reaction-layer. Recently, Arbizzani et al $^{34,35}$ have studied a passive DMFC with PEDOT-PSSA supported Pt-Ru as catalyst both for its anode and cathode more so to demonstrate mixed (electron + proton) conduction in PEDOT-PSSA supported $\mathrm{Pt}-\mathrm{Ru}$ catalyst and have reported mass activity for PEDOT-PSSA supported Pt-Ru catalyst to be similar to Vulcan XC-72 supported $\mathrm{Pt}-\mathrm{Ru}$ catalyst. By contrast, Patra et $a l^{36}$ have reported higher electrochemical activity towards methanol oxidation with Pt dispersed on PEDOT in relation to carbon-supported Pt.

The present study is an attempt to resolve the aforesaid paradox. The study comprises a detailed investigation on the electro-catalytic behaviour of PEDOT-PSSA supported Pt-Ru towards methanol oxidation wherein a comparison of the performance data for DMFCs employing mixed-conductingPEDOT-PSSA-supported Pt-Ru and carbon-supported $\mathrm{Pt}-\mathrm{Ru}$ suggests the former to be superior.

\section{Experimental}

\subsection{Materials}

All the chemicals used were of analytical grade. Chloroplatinic acid and ruthenium trichloride were purchased from Alfa Aesar. (3,4-ethylenedioxythiophene) EDOT was procured from Aldrich. Sodium salt of polystyrenesulfonic acid, formaldehyde, ferric nitrate, and methanol were obtained from Acros Organics and were used as received. Vulcan XC 72R carbon was obtained from Cabot
Corporation. Polytetrafluroethylene (PTFE) and 5 wt.\% Nafion solution were procured from Dupont and were used as received. De-ionized water $(18 \mathrm{M} \Omega \mathrm{cm})$ was used during the study.

\subsection{Synthesis of PEDOT-PSSA composite}

PEDOT-PSSA composite was synthesized using the procedure described elsewhere. ${ }^{37}$ In brief, EDOT was polymerized by mixing an aqueous solution of NaPSS with required amount of EDOT monomer and stirred for $30 \mathrm{~min}$. To the aforesaid admixture, an excess of $\mathrm{Fe}\left(\mathrm{NO}_{3}\right)_{3} \cdot 9 \mathrm{H}_{2} \mathrm{O}$ dissolved in minimum amount of water was added drop-wise under stirring at room temperature $\left(\sim 25^{\circ} \mathrm{C}\right)$. The dark-blue coloured suspension thus obtained was filtered, washed copiously with de-ionized water. The resultant composite was dried at $50^{\circ} \mathrm{C}$ under vacuum.

\subsection{Preparation of Pt-Ru nanoparticle on PEDOT-PSSA and on Vulcan XC-72R carbon}

For supporting 1: 1 Pt-Ru on PEDOT-PSSA, about $0.4 \mathrm{~g}$ of PEDOT-PSSA was sonicated in an ultrasonic bath with water for $15 \mathrm{~min}$ to which the required amount of chloroplatinic acid and ruthenium chloride were added as precursors. The mixture was stirred at room temperature for $30 \mathrm{~min}$ and formaldehyde was added to it followed by refluxing for $1 \mathrm{~h}$ at $80^{\circ} \mathrm{C}$. After cooling, it was washed with copious amount of water, filtered and dried at $50^{\circ} \mathrm{C}$ for $4 \mathrm{~h}$. Similarly, $1: 1 \mathrm{Pt}-\mathrm{Ru}$ on Vulcan XC-72R carbon was obtained; in brief, the mixture containing $0.4 \mathrm{~g}$ of Vulcan XC-72R carbon and catalyst precursor was stirred at room temperature followed by heating up to $80^{\circ} \mathrm{C}$. Subsequently, the $\mathrm{pH}$ of the solution was adjusted to 8.5 using $0.5 \mathrm{M} \mathrm{NaOH}$ solution. About $2 \mathrm{ml}$ of $37 \mathrm{wt} . \%$ formaldehyde was added to it and kept under stirring for $1 \mathrm{~h}$. After cooling, it was washed with copious amount of water, filtered and dried at $50^{\circ} \mathrm{C}$ for $4 \mathrm{~h}$.

\subsection{Physicochemical characterization}

Formation and doped states of PEDOT were confirmed by recording Fourier-transform infra-red spectra on a Thermo Nicolet (Model Nexus 670) spectrometer. X-ray powder diffraction (XRD) patterns for the catalysts were obtained on a Philips Pan Analytical X-ray Diffractometer. The supported 
catalysts were also examined under Scanning Electron Microscope (SEM-Model JEOL JSM 5400). The atomic compositions of $\mathrm{Pt}-\mathrm{Ru}$ particles supported on PEDOT-PSSA and Vulcan XC 72R were analysed by Energy Dispersive Analysis of X-rays (EDAX) available with the SEM instrument.

\subsection{Fabrication of membrane electrode assembly (MEA)}

15 wt.\% teflonised Toray-TGP-H-120 carbon paper of $0.37 \mathrm{~mm}$ thickness was used as the backing layer. To prepare the gas-diffusion layer (GDL), Vulcan $\mathrm{XC}-72 \mathrm{R}$ was suspended in cyclohexane and agitated in an ultrasonic water bath for $30 \mathrm{~min}$. To this solution, $15 \mathrm{wt} . \%$ poly (tetrafluroethene) (PTFE) suspension in $2 \mathrm{~mL}$ ammonia was added with continuous agitation to form a slurry that was coated onto the backing layer uniformly until required loading of $1.5 \mathrm{mg} \mathrm{cm}^{-2}$ carbon was attained. GDL thus obtained was sintered in an air oven at $350^{\circ} \mathrm{C}$ for $30 \mathrm{~min}$. For anode reaction layer, $\mathrm{Pt}-\mathrm{Ru}-$ impregnated PEDOT-PSSA and Vulcan XC 72R were dispersed in ethanol and ultrasonicated for $30 \mathrm{~min}$ followed by the addition of required amount of Nafion solution (5 wt.\%) and the resultant slurry was ultrasonicated for $1 \mathrm{~h}$. The slurry thus obtained was coated onto the anode GDL till $2 \mathrm{mg} \mathrm{cm}^{-2}$ of $\mathrm{Pt}-\mathrm{Ru}$ loading was attained; similarly, all cathode GDLs were coated with $2 \mathrm{mg} \mathrm{cm}^{-2} \mathrm{Pt}$. A thin layer of 1:1 solution of $5 \mathrm{wt} . \%$ Nafion and isopropyl alcohol was applied onto the surface of the electrode and the membrane electrode assembly was obtained by sandwiching the pre-treated Nafion-117 membrane between the two electrodes followed by its hot-pressing at $130^{\circ} \mathrm{C}$ for $3 \mathrm{~min}$ at a pressure of $60 \mathrm{~kg} \mathrm{~cm}^{-2}$.

\subsection{Preparation of the working electrode}

The glassy carbon (GC) disk with geometrical area $0.071 \mathrm{~cm}^{2}$ was used as working-electrode substrate for electrochemical measurements. The electrode was polished to a mirror finish with $0.06 \mu \mathrm{m}$ alumina followed by rinsing in double-distilled water in an ultrasonicator. To prepare the working electrode, slurries of $60 \mathrm{wt} . \% \mathrm{Pt}-\mathrm{Ru} / \mathrm{PEDOT}-\mathrm{PSSA}$ and 60 wt.\% Pt-Ru/Vulcan XC $72 \mathrm{R}$ were prepared by taking $5 \mathrm{mg}$ of the catalyst in $1 \mathrm{ml}$ of deionized water along with 5 wt.\% Nafion as a binder. $5 \mu$ l of the dispersion was pipetted out on the top of the GC and the electrode was dried at room temperature $\left(\sim 25^{\circ} \mathrm{C}\right)$ to yield a Pt-Ru loading of $\sim 200 \mu \mathrm{g} / \mathrm{cm}^{2}$.

\subsection{Electrochemical characterization}

Electrochemical measurements were carried out using a potentiostat (Autolab PGSTAT 30) with conventional three electrode cell comprising a GC working electrode, Pt foil as the counter electrode and saturated calomel electrode (SCE) as the reference electrode. Cyclic voltammetric (CV) studies were performed in a solution containing $2 \mathrm{M}$ $\mathrm{CH}_{3} \mathrm{OH}$ solution in $0.5 \mathrm{M} \mathrm{H}_{2} \mathrm{SO}_{4}$ at a scan rate of $50 \mathrm{mV} \mathrm{s}^{-1}$. Prior to the measurements nitrogen gas was purged for nearly $30 \mathrm{~min}$, and stable and reproducible voltammograms were recorded after cycling in the potential region between $-0.25 \mathrm{~V}$ and $1 \mathrm{~V}$ (vs SCE) in $0.5 \mathrm{M} \mathrm{H}_{2} \mathrm{SO}_{4}$ solution at $25^{\circ} \mathrm{C}$. Chronoamperometry tests were conducted using a three electrode cell in a solution containing $2 \mathrm{M} \mathrm{C \textrm {CH } _ { 3 } \mathrm { OH }}$ solution in $0.5 \mathrm{M} \mathrm{H}_{2} \mathrm{SO}_{4}$ at $0.6 \mathrm{~V}$ (vs $\mathrm{SCE}$ ) for $3600 \mathrm{~s}$

\subsection{Performance evaluation of DMFCs}

MEAs were performance evaluated in a $4 \mathrm{~cm}^{2}$ fuelcell with parallel and parallel serpentine flow-field machined on graphite plates (Schunk Kohlenstofftechnic) for anode and cathode, respectively. For single cell polarization experiment an aqueous solution of $2 \mathrm{M}$ methanol was fed to the anode of the DMFC through a peristaltic pump at $5 \mathrm{ml} \mathrm{min}^{-1}$ and humidified oxygen was fed to the cathode using a mass-flow controller (Aalborg Instruments and Controls, US) at a constant flow rate of $50 \mathrm{ml} \mathrm{min}^{-1}$ at atmospheric pressure. After equilibration, the fuel cell was tested at $70^{\circ} \mathrm{C}$ by taking galvanostatic polarisation data using a LCN100-36 electronic load procured from Bitrode Corporation, US. For halfcell polarization studies a three-electrode configuration was used. Gaseous hydrogen was fed to the cathode which served as both counter and reference electrodes. These measurements were carried out using a steady-state galvanostatic measurement at a scan rate of $10 \mathrm{~mA} \mathrm{~s}^{-1}$. After DMFC became stable, it was subjected to ac impedance measurements in the frequency range between $10 \mathrm{kHz}$ and $0 \cdot 1 \mathrm{~Hz}$ at sinusoidal-potential-signal amplitude of $10 \mathrm{mVs}^{-1}$ by using an Autolab-PGSTAT 30 at an operating cell voltage of $0.4 \mathrm{~V}$. 


\section{Results and discussion}

\subsection{Physicochemical characterization}

FT-IR spectra for pristine PEDOT-PSSA composite and $60 \mathrm{wt} . \% \mathrm{Pt}-\mathrm{Ru}$ supported on PEDOT-PSSA composite are shown in figure $1(\mathrm{a})$ and (b), respectively. Absorption peaks at 1320 and $1520 \mathrm{~cm}^{-1}$ correspond to $\mathrm{C}-\mathrm{C}$ or $\mathrm{C}=\mathrm{C}$ stretching modes of thiophene ring, while $\mathrm{C}-\mathrm{S}$ vibration modes are seen at $682 \mathrm{~cm}^{-1}, 830 \mathrm{~cm}^{-1}$ and $927 \mathrm{~cm}^{-1}$, and peaks at $1086 \mathrm{~cm}^{-1}, 1132 \mathrm{~cm}^{-1}$ and $1200 \mathrm{~cm}^{-1}$ are assigned to stretching mode of ethylene dioxy $(\mathrm{C}-\mathrm{O}-\mathrm{C})$ group. ${ }^{38}$

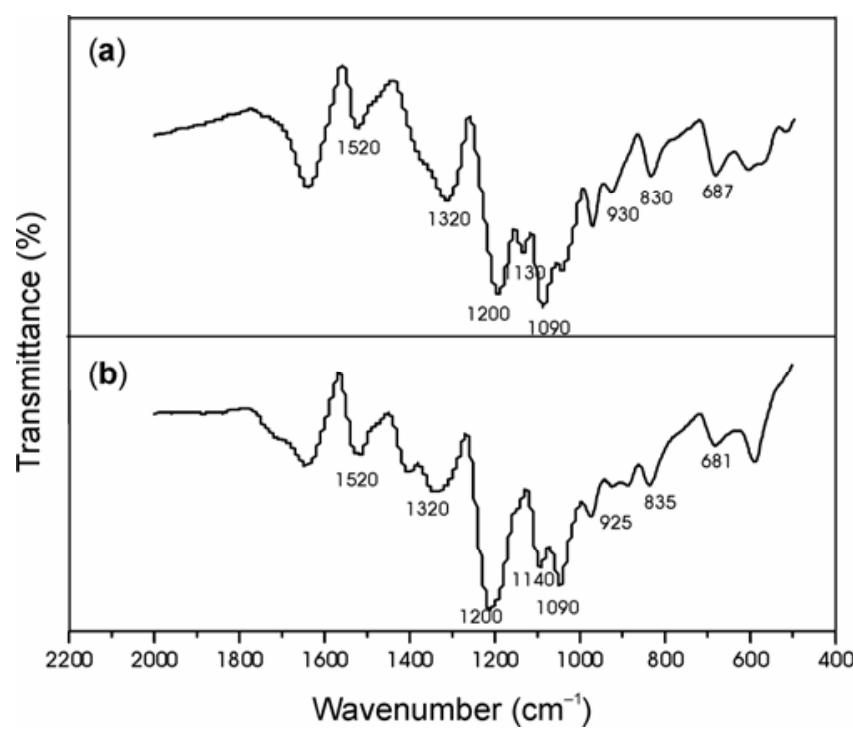

Figure 1. FTIR spectra for (a) PEDOT-PSSA powder and (b) $(1: 1)$ Pt-Ru/PEDOT-PSSA composite.

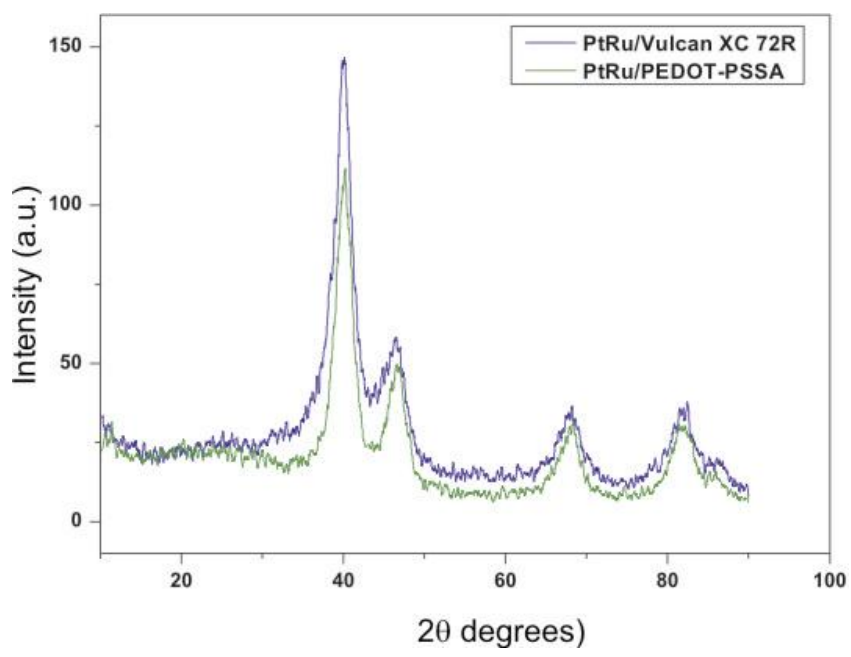

Figure 2. Powder X-ray diffraction patterns for Pt$\mathrm{Ru} / \mathrm{PEDOT}-\mathrm{PSSA}$ and Pt-Ru/Vulcan XC 72R
Both the spectra are nearly identical suggesting PEDOT structure was retained even after incorporating the catalyst. The presence of characteristic peaks at different vibration modes in the spectra confirms the formation of PEDOT.

Both the catalysts, namely Pt-Ru/Vulcan XC 72R and Pt-Ru/PEDOT-PSSA, are characterized by $\mathrm{XRD}$. The powder X-ray diffraction patterns for the catalysts as shown in figure 2 exhibit diffraction peaks corresponding to (111), (200), (220), and (311) reflections akin to the face-centered-cubic $(f c c)$ crystal structure for Pt. Incorporation of $\mathrm{Ru}$ into the $f c c$ Pt structure is reflected by the shift in the diffraction peaks to higher values of $2 \theta^{39}$ Absence of characteristic reflections associated with a hexagonal close packed $(h c p)$ structure of $\mathrm{Ru}$ implies formation of Pt-Ru structure. Differences appear only in the full-width at half maximum (FWHM) of the reflection peaks indicating a difference in the average particle sizes. The average particle sizes for the Pt-Ru particles supported onto PEDOT-PSSA and Vulcan XC 72R as evaluated by the Scherrer equation are 6 and $8 \mathrm{~nm}$, respectively.

The electron micrographs for the catalysts are obtained using a SEM and their elemental composition determined by EDAX. The EDAX data for both Pt$\mathrm{Ru} / \mathrm{PEDOT}-\mathrm{PSSA}$ and Pt-Ru/Vulcan XC 72R catalysts are shown in figure 3(a) and (b) along with their electron micrographs. The electron micrograph for Pt-Ru-dispersed onto PEDOT-PSSA shows a particulate morphology on the base polymer-matrix suitable for effective dispersion of Pt-Ru. Quantitative analysis by EDAX indicates Pt loadings of $36.4 \mathrm{wt} . \%$ and $37.2 \mathrm{wt} . \%$ and $\mathrm{Ru}$ loadings of 18.9 wt. $\%$ and 17.4 wt. $\%$ for Pt-Ru/PEDOT-PSSA and $\mathrm{Pt}-\mathrm{Ru} / \mathrm{Vulcan} \mathrm{XC}-72$, respectively, as against the desired loadings of $40 \mathrm{wt} . \% \mathrm{Pt}$ and $20 \mathrm{wt} . \% \mathrm{Ru}$.

\subsection{Performance Evaluation of the catalysts towards methanol electro-oxidation}

Catalytic activity of Pt-Ru supported on PEDOTPSSA is investigated towards electro-oxidation of methanol. Figure 4 shows cyclic voltammograms between -0.25 and $1.0 \mathrm{~V}$ (vs SCE) for the Pt$\mathrm{Ru} / \mathrm{PEDOT}-\mathrm{PSSA}$ and Pt-Ru/Vulcan XC 72R catalysts in a solution containing $2 \mathrm{M} \mathrm{CH}_{3} \mathrm{OH}$ in $0.5 \mathrm{M}$ $\mathrm{H}_{2} \mathrm{SO}_{4}$. Changes in electrode reaction rates were estimated from the peak current density. In the voltammograms, the forward current peak $\left(I_{f}\right)$ is attributed to the oxidation of methanol and the backward 
peak is due to the oxidation of adsorbed intermediates. PEDOT-PSSA supported $\mathrm{Pt}-\mathrm{Ru}$ exhibits a forward current peak of $10 \mathrm{~mA} \mathrm{~cm}^{-2}$ at $0.6 \mathrm{~V}$ (vs SCE) and shows higher methanol oxidation current in relation to carbon-supported $\mathrm{Pt}-\mathrm{Ru}$ catalyst. This could be due to mixed-conducting nature of PEDOT-PSSA that enhances proton and electron transport within the anode catalyst, ameliorating the utilization of $\mathrm{Pt}-\mathrm{Ru}$ catalyst.

In the literature, ${ }^{40-42}$ it is reported that the longterm activity of $\mathrm{Pt}$ is due to the competitive adsorption of reaction intermediates on the surface of polyaniline. Accordingly, it is evident that the catalytic activity of electrocatalyst varies with the support. Cumulative effect of $\mathrm{Ru}$ and polymer matrix that adsorbs reaction intermediates makes $\mathrm{Pt}-\mathrm{Ru}$ supported on PEDOT-PSSA tolerant to carbonaceous species accumulation. The mass activity $\left(\mathrm{mA} / \mathrm{mg}_{\mathrm{Pt}-\mathrm{Ru}}\right)$ and $I_{f} / I_{b}$ ratio for methanol oxidation at the respective peak-potentials are given in table 1. Although the $I_{f} / I_{b}$ ratio is almost the same for both the catalysts, the improved mass activity for PtRu/PEDOTPSSA elucidates ameliorated effect of PEDOTPSSA higher efficiency over Vulcan XC72R. Supe-
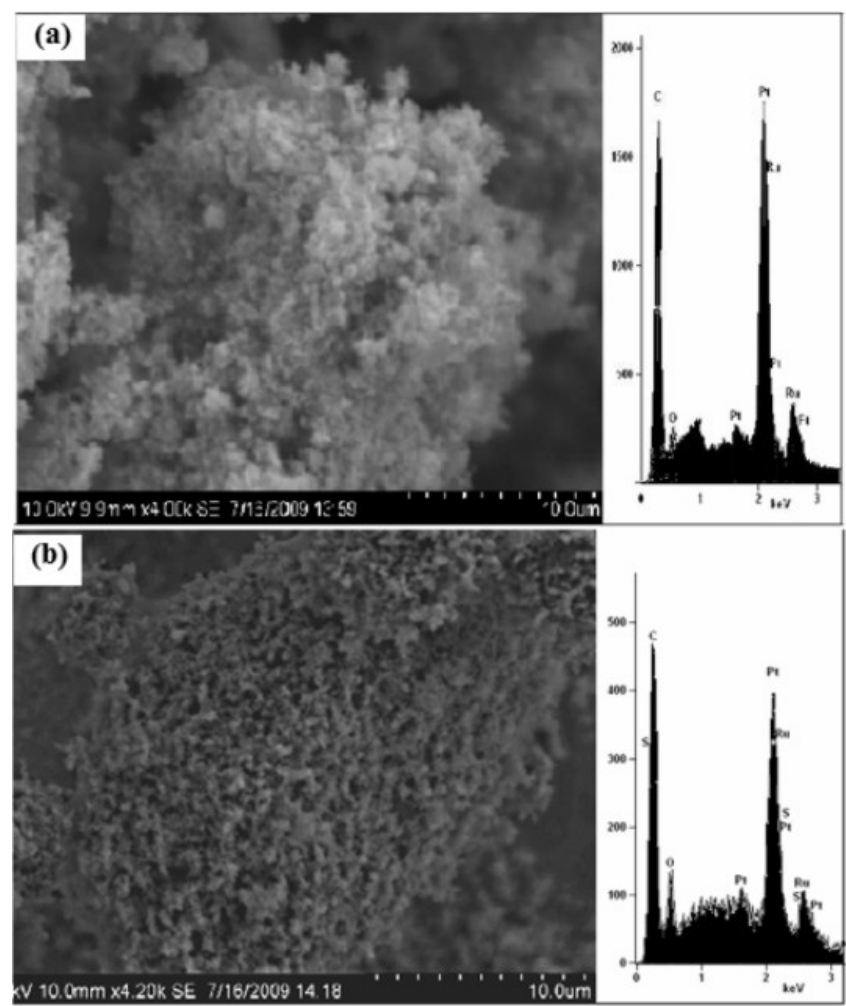

Figure 3. SEM images and EDAX spectra for (a) $\mathrm{Pt}-$ $\mathrm{Ru} / \mathrm{PEDOT}-\mathrm{PSSA}$ and (b) Pt/Vulcan XC 72R. The scale bar in both figures corresponds to $10 \mu \mathrm{m}$. rior wetting characteristics of PEDOT-PSSA composite in methanol may lead to higher utilization of the internal surface-area of the composite. Besides, the intrinsic proton conductivity of the composite allows methanol oxidation reaction to take place across the catalyst layer and reduces the number of phases for active reaction, which increases the active contact sites between the reactant and the catalyst. The presence of ionicallyconducting PSSA in PEDOT may also improve the catalytic property of $\mathrm{Pt}-\mathrm{Ru}$ in PEDOT-PSSA supported catalyst.

\subsection{Anode polarization}

To further evaluate the performance of $\mathrm{Pt}-\mathrm{Ru}$ supported on PEDOT-PSSA and Vulcan XC 72R carbon towards methanol oxidation, DMFCs are assembled and anode polarization data are obtained
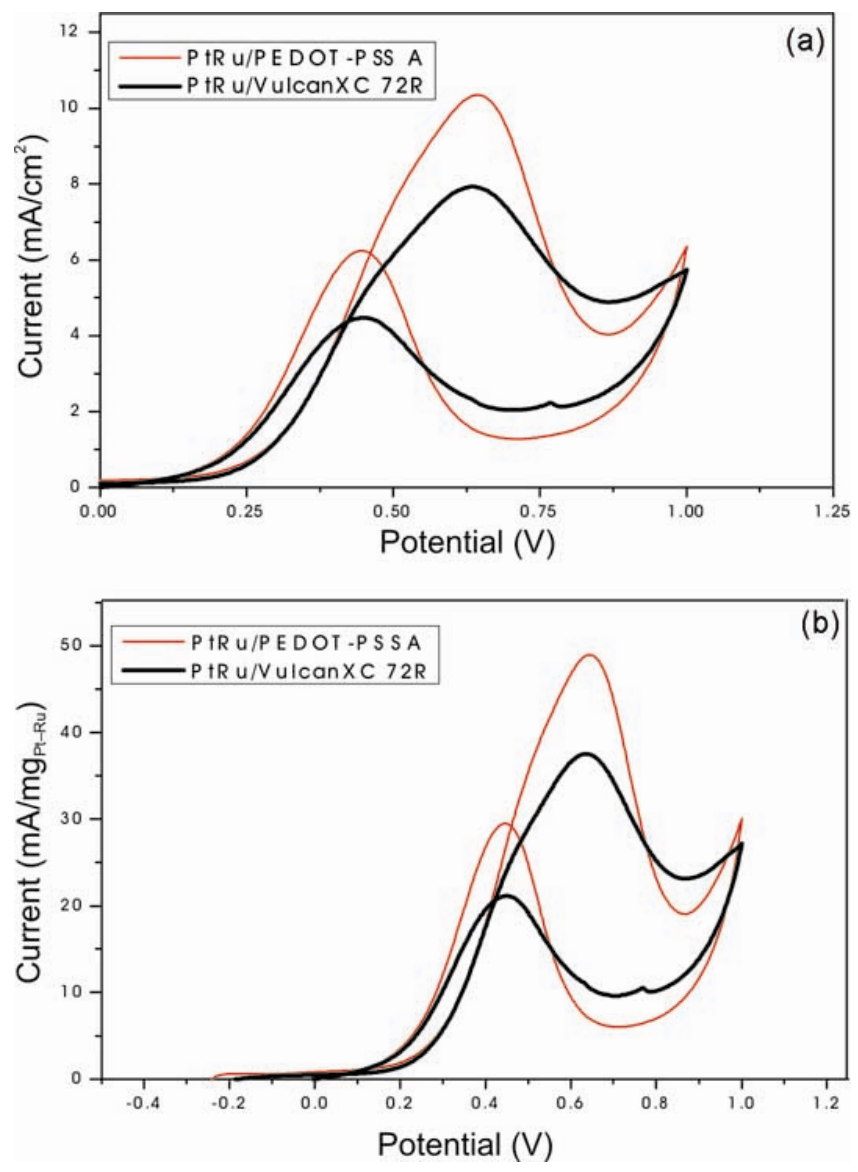

Figure 4. Cyclic voltammograms for methanol electrooxidation of Pt-Ru/PEDOT-PSSA and Pt-Ru/Vulcan $\mathrm{XC} 72 \mathrm{R}$ electrodes in $2 \mathrm{M}$ methanol in $0.5 \mathrm{M} \mathrm{H}_{2} \mathrm{SO}_{4}$ solution at scan rate of $50 \mathrm{mV} / \mathrm{s}$. (a) Normalized to area of the electrode. (b) Normalized to metal loading. 
Table 1. Methanol oxidation data for Pt-Ru/PEDOT-PSSA and Pt-Ru/Vulcan XC 72R electrodes.

\begin{tabular}{lccccc}
\hline Catalyst & $\begin{array}{c}\text { Mass activity } \\
(\mathrm{mA} / \mathrm{mg} \text { of Pt-Ru) }\end{array}$ & $\begin{array}{c}\text { Anodic peak } \\
\text { potential (V) }\end{array}$ & $I_{f} / I_{b}$ ratio & $\begin{array}{c}\text { Activity } \\
\left(\mathrm{A} / \mathrm{mg}_{\mathrm{Pt}-\mathrm{Ru}} / \mathrm{cm}^{2}\right)\end{array}$ & $\begin{array}{c}\mathrm{Pt}-\mathrm{Ru} \text { loading } \\
\left(\mu \mathrm{g} / \mathrm{cm}^{2}\right)\end{array}$ \\
\hline Pt-Ru/PEDOT-PSSA & 48.97 & 0.638 & 1.8 & 0.689 & 210 \\
Pt-Ru/Vulcan XC 72R & 37.51 & 0.631 & 1.72 & 0.528 & 211 \\
\hline
\end{tabular}

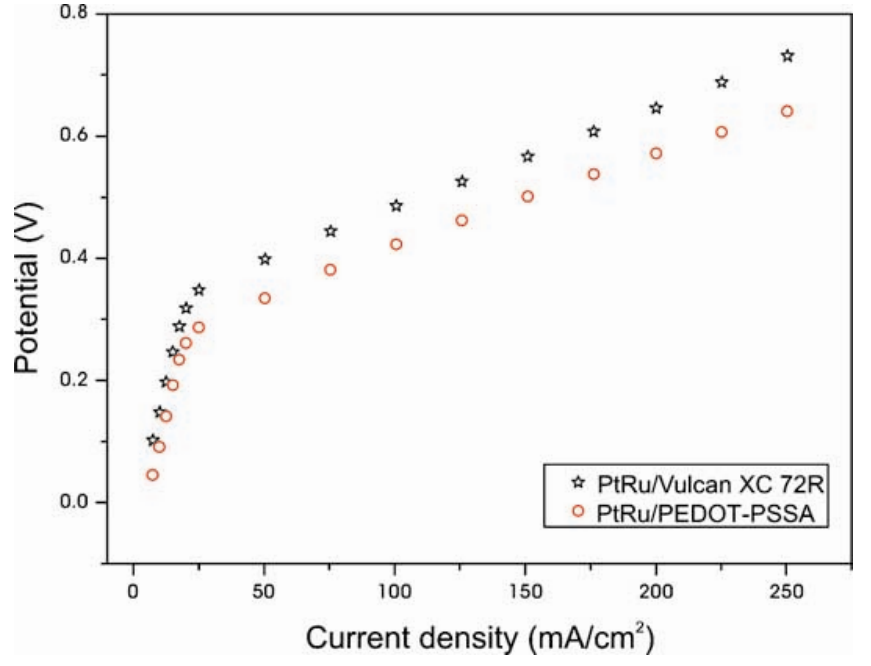

Figure 5. Anodic half-cell polarization behaviour of $\mathrm{Pt}-\mathrm{Ru} / \mathrm{PEDOT}$ - PSSA and Pt-Ru/Vulcan XC $72 \mathrm{R}$ at $70^{\circ} \mathrm{C}$ cell mode with $2 \mathrm{M} \mathrm{CH}_{3} \mathrm{OH}$ at anode at a flow rate of $1 \mathrm{ml} \mathrm{min}{ }^{-1}$ and with $\mathrm{N}_{2}$ streams at cathode (scan rate = $10 \mathrm{mV} / \mathrm{s})$.

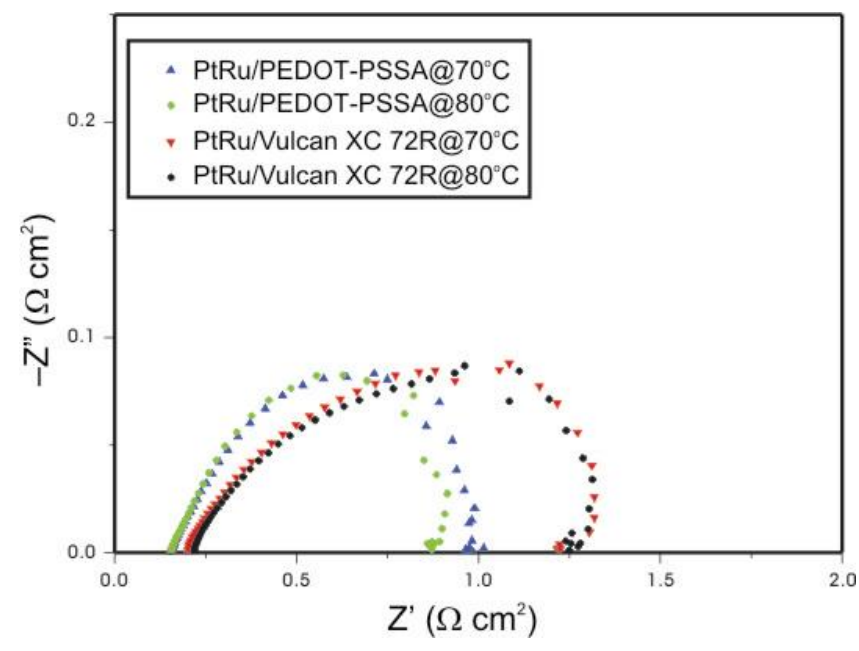

Figure 6. The Nyquist plot of DMFC assembled with $\mathrm{Pt}-\mathrm{Ru} / \mathrm{PEDOT}-\mathrm{PSSA}$ and $\mathrm{Pt}-\mathrm{Ru} / \mathrm{Vulcan} \mathrm{XC} 72 \mathrm{R}$ as anode material at $0.4 \mathrm{~V}$ at various temperatures in cell mode with $2 \mathrm{M} \mathrm{CH}_{3} \mathrm{OH}$ at anode at a flow rate of $1 \mathrm{ml}$ $\min ^{-1}$ and with $\mathrm{O}_{2}$ streams at cathode.

as depicted in figure 5. The potential of $\mathrm{Pt}-\mathrm{Ru} /$ PEDOT-PSSA anode is $0.5 \mathrm{~V}$ (vs DHE) at $150 \mathrm{~mA} \mathrm{~cm}{ }^{-2}$, which is about $65 \mathrm{mV}$ lower in com- parison with $\mathrm{Pt}-\mathrm{Ru} / \mathrm{Vulcan} \mathrm{XC} 72 \mathrm{R}$ anode. This clearly indicates that PEDOT-PSSA supported Pt$\mathrm{Ru}$ catalyst exhibits a higher catalytic activity for methanol oxidation.

\subsection{Impedance spectroscopy}

Impedance measurements (figure 6) are carried out at various temperatures and the results are interpreted by assuming an equivalent circuit as described by Seo and Lee. ${ }^{43}$ To mitigate the influence of mass transport, impedance measurements are carried out at $0.4 \mathrm{~V}$. It is observed that both ohmic and activation losses decrease as the cell temperature increases. The bulk (ionic + electronic) and contact resistances are observed at high frequencies. The diameter of the semicircle representing the charge-transfer resistance for PEDOT-PSSA and Vulcan XC $72 \mathrm{R}$ supported catalyst is about $0.80 \Omega \mathrm{cm}^{2}$ and $1.08 \Omega \mathrm{cm}^{2}$, respectively. The resistance of Pt-Ru/PEDOT-PSSA is lower in relation to $\mathrm{Pt}-\mathrm{Ru} / \mathrm{Vulcan} \mathrm{XC} 72 \mathrm{R}$ as evident from the intercept of real impedance axis at low frequencies. It is presumed that the incorporation of PSSA into PEDOT increases the electronic resistance of the PEDOTPSSA composite as also adds up to the proton conductivity that consequently decreases the total resistance of the system as suggested by Drillet et al. ${ }^{33}$ The increase in proton conduction in the catalyst layer by PSSA-doped PEDOT creates a two-phase boundary necessary for electron and ion transfer as opposed to the three-phase boundary present when carbon is used as the support. ${ }^{37}$

\subsection{Chronoamperometry}

Chronoamperometric studies are conducted at $0.6 \mathrm{~V}$ (vs SCE) for electrodes with Pt-Ru/PEDOT-PSSA and $\mathrm{Pt}-\mathrm{Ru} /$ Vulcan $\mathrm{XC} 72 \mathrm{R}$ as the support material for about $3600 \mathrm{~s}$ to establish its stability towards methanol oxidation. To this end, working electrode, reference and counter electrodes are placed in a solution containing $2 \mathrm{M}$ methanol in $0.5 \mathrm{M} \mathrm{H}_{2} \mathrm{SO}_{4}$. 
From figure 7, it is seen that current degrades rapidly for $500 \mathrm{~s}$, which could be due to the formation of intermediate species during methanol oxidation reaction. ${ }^{44}$ Subsequently, the current response corresponding to Pt-Ru/PEDOT-PSSA stabilizes gradually unlike the case for Pt-Ru/Vulcan XC 72R. This characteristic of electrode makes them useful especially where fast start-up time or low equilibration times for DMFCs are desirable.

Corrosion current for both PEDOT-PSSA and Vulcan XC $72 \mathrm{R}$ are obtained under conditions stimulating carbon corrosion. The as-prepared electrodes were immersed in nitrogen purged $0.5 \mathrm{M}$ sul-

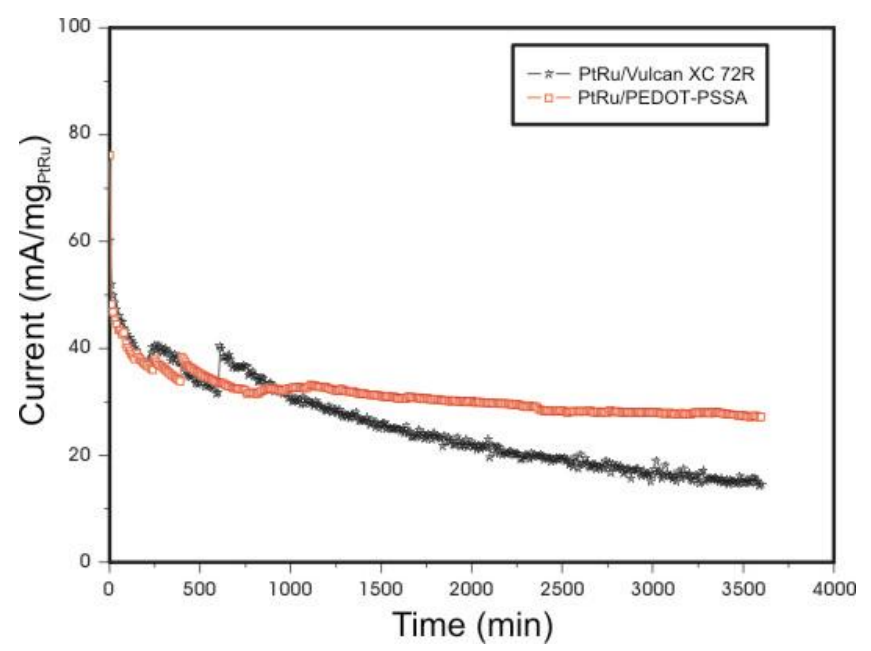

Figure 7. Chronoamperometric data for Pt-Ru/PEDOTPSSA and $\mathrm{Pt}-\mathrm{Ru} /$ Vulcan $\mathrm{XC} 72 \mathrm{R}$ at $0.6 \mathrm{~V}$ in $0.5 \mathrm{M}$ $\mathrm{H}_{2} \mathrm{SO}_{4}$ consisting of $2 \mathrm{M}$ methanol.

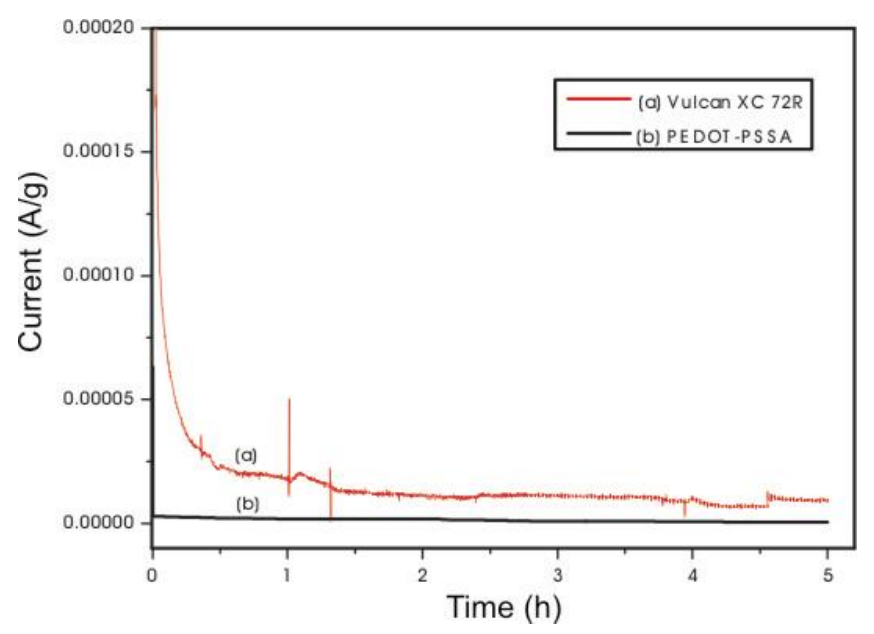

Figure 8. Chronoamperometric curve for Vulcan $\mathrm{XC}$ $72 \mathrm{R}$ and PEDOT-PSSA measured at $0.9 \mathrm{~V}$ in $\mathrm{N}_{2}$ purged $0.5 \mathrm{M} \mathrm{H}_{2} \mathrm{SO}_{4}$ phuric acid solution and current response as a function of time is measured at $0.9 \mathrm{~V}$ ( $\mathrm{vs} \mathrm{Ag} / \mathrm{AgCl}$ ). The chronoamperometric data (figure 8) shows lesser corrosion current for PEDOT-PSSA compared to Vulcan XC 72R for duration of $5 \mathrm{~h}$. This suggests PEDOT-PSSA to be corrosion resistant and durable when used as a catalyst support.

\subsection{Direct methanol fuel cell performance test}

The overall fuel-cell performance for the $\mathrm{Pt}-\mathrm{Ru}$ nanoparticles supported on to PEDOT-PSSA and on to Vulcan $\mathrm{XC} 72 \mathrm{R}$ is compared in a practical DMFC. Figure 9 compares the performance of the DMFC anode comprising Pt-Ru/PEDOT-PSSA and $\mathrm{Pt}-\mathrm{Ru} / \mathrm{Vulcan} \mathrm{XC} 72 \mathrm{R}$ nanocatalysts while using 2 $\mathrm{M}$ methanol at $70^{\circ} \mathrm{C}$ under similar test conditions. Table 2 displays the performance in $W / g_{\mathrm{Pt}-\mathrm{Ru}}$ with corresponding loading of the noble metals used in both anode and cathode. Anode comprising $\mathrm{Pt}-\mathrm{Ru}$ supported PEDOT-PSSA shows higher open-circuit voltage and performance over the entire range of current density in relation to $\mathrm{Pt}-\mathrm{Ru}$ supported on the Vulcan XC 72R. The DMFC with anode containing Pt-Ru/PEDOT-PSSA that yields a peak power density of $71 \mathrm{~mW} \mathrm{~cm}^{-2}$, which is about $30 \%$ higher than the DMFC with anode containing $\mathrm{Pt}-\mathrm{Ru}$ supported on the Vulcan XC 72R yields a peak power density of only $51 \mathrm{~mW} \mathrm{~cm}^{-2}$. These data are consistent with the mass activity data obtained from the CV studies. It appears that further improvements in the conductivity of support and morphology of the $\mathrm{Pt}-$

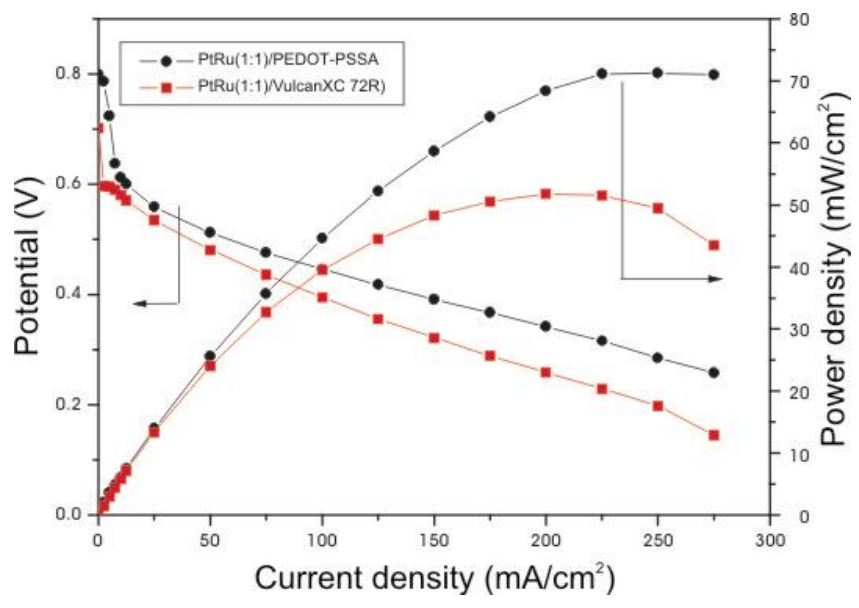

Figure 9. Comparison of DMFC performance using PEDOT-PSSA supported Pt-Ru and Vulcan XC 72R supported $\mathrm{Pt}-\mathrm{Ru}$ catalysts at anode with $2 \mathrm{M}$ methanol at $70^{\circ} \mathrm{C}$. 
Table 2. Current and $P_{\max }$ data for Pt-Ru/PEDOT-PSSA and Pt-Ru/Vulcan XC 72R electrodes employed in DMFC.

\begin{tabular}{llccc}
\hline S. No & Anode support & Pt-Ru loading & Current $\left(\mathrm{A} \mathrm{g}^{-1} \mathrm{Pt}-\mathrm{Ru}\right)$ & Power $_{\mathrm{max}}\left(\mathrm{W} \mathrm{g} \mathrm{g}^{-1} \mathrm{Pt}-\mathrm{Ru}\right)$ \\
\hline MEA 1 & $\mathrm{Pt}-\mathrm{Ru} /$ PEDOT-PSSA & $2 \mathrm{mg} / \mathrm{cm}^{2}\left(1 \cdot 3 \mathrm{mg} / \mathrm{cm}^{2}\right.$ of Pt $)$ & 112.5 & $35 \cdot 5$ \\
MEA 2 & $\mathrm{Pt}-\mathrm{Ru} /$ Vulcan XC 72R & $2 \mathrm{mg} / \mathrm{cm}^{2}\left(1.3 \mathrm{mg} / \mathrm{cm}^{2}\right.$ of Pt $)$ & 100 & $25 \cdot 5$ \\
\hline
\end{tabular}

*Pt loading on cathode kept constant at $2 \mathrm{mg} / \mathrm{cm}^{2}$ for both MEAs.

Ru/PEDOT-PSSA can help enhancing the cell performance.

\section{Conclusions}

The present study projects PEDOT-PSSA conducting-polymer composite as a promising support material for Pt-Ru and its ameliorating effect towards methanol-oxidation reaction. Electrochemical data demonstrate that $\mathrm{Pt}-\mathrm{Ru} / \mathrm{PEDOT}-\mathrm{PSSA}$ has higher mass-activity than Pt-Ru/Vulcan XC72R. The ameliorating effect of the mixed-conducting PEDOTPSSA composite is reflected by the improved performance of the DMFC and the related impedance measurements where the total system-resistance is found to be lower.

\section{Acknowledgement}

Financial support from the Council of Scientific and Industrial Research (CSIR), New Delhi under an EFYP supra-institutional project is gratefully acknowledged.

\section{References}

1. Larminie J and Dicks A 2003 Fuel cell system explained (New York: Wiley)

2. Scott K and Shukla A K 2007 Modern aspects of electrochemistry (Springer) pp 127-227

3. Ren X M, Zelenay P, Thomas A, Davey J and Gottesfeld S 2000 J. Power Sources 86111

4. Hampson N A, Willars M J and McNicol B D $1979 \mathrm{~J}$. Power Sources 4191

5. Parsons R and VanderNoot T J 1988 J. Electroanal. Chem 9257

6. Iwasita-Vielstich $\mathrm{T}$, Tobias $\mathrm{C} \mathrm{W}$ and Gerischer $\mathrm{H}$ 1990 Advances in electrochemical science and engineering (Weinheim: VCH) vol. 1, p. 127

7. Cameron D S Hards G A and Thompsett D 1992 Proc. Electrochem. Soc. 10

8. Vielstich W and Iwasita T 1997 Handbook of heterogeneous catalysis (Chichester: Wiley) vol. 4

9. Kordesch K and Simader G 1996 Fuel cells and their application (Weinheim: VCH)
10. Selvarani G, Maheswari S, Sridhar P, Pitchumani S and Shukla A K 2009 J. Electrochem. Soc. 156 B1354

11. Liu H, Song C, Zhang L, Zhang J, Wang H and Wilkinson D P 2006 J. Power Sources 15595

12. Liu Z, Ling X Y, Su X and Lee J Y 2004 J. Phys. Chem. B108 8234

13. Uchida M, Aoyama Y, Tanabe N, Yanagihara N, Eda $\mathrm{N}$ and Ohta A 1995 J. Electrochem. Soc. 1422572

14. Aramata A, Kodera T and Masuda M $1988 \mathrm{~J}$. Appl. Electrochem. 18577

15. Roy S C, Christensen P A, Hamnett A, Thomas K M and Trapp V 1996 J. Electrochem. Soc. 1433073

16. Liu Z L, Lin X H, Lee J Y, Zhang W, Han M and Gan L M 2002 Langmuir 184054

17. Li W Z, Liang C H, Zhou W J, Qiu J S, Zhou Z H, Sun G Q and Xin Q, 2003 J. Phys. Chem. B107 6292

18. Prabhuram J, Zhao T S, Tang $Z \mathrm{~K}$, Chen $\mathrm{R}$ and $\mathrm{Z} X$ Liang 2006 J. Phys. Chem. B110 5245

19. Y C Liu, X P Qiu, Y Q Huang and W T Zhu 2002 Carbon 402375

20. Salaneck W R, Clark D T and Samuelsen E J 1991 Science and application of conducting polymers (IOP Publishing)

21. Feast W J, Tsibouklis J, Pouwer K L, Groenendaal L and Meijer E W 1996 Polymer 375017

22. Chiang J-C and MacDiarmid A G 1986 Synt. Met. 13 193

23. Warren L F and Anderson D P 1987 J. Electrochem. Soc. 134101

24. Kitani A, Akashi T, Sugimoto K and Ito S 2001 Synth. Met. 1211301

25. Liu F J, Huang L M, Wen T C and Gopalan A 2007 Synth. Met. 157651

26. Kost K M, Bartak D E, Kazee B and Kuwana T 1988 Anal. Chem. 602379

27. Rajesh B, Thampi K R, Bonard J M, Mathieu H J, Xanthopoulos N and Viswanathan B 2003 Chem. Commun. 162033

28. Wu G, Li L, Li J H and Xu 2006 J. Power Sources 155118

29. Selvaraj V and Alagar M 2007 Electrochem. Commun. 91145

30. Swathirajan S and Mikhali Y M 1992 J. Electrochem. Soc. 1392105

31. Qi Z and Pickup P G 1998 Chem. Commun. 2299

32. Yamato H, Ohwa M and Wernet W 1995 J. Electroanal. Chem. 397163

33. Drillet J-F, Dittmeyer R and JÜttner K 2007 J. Appl. Electrochem. 371219 
34. Arbizzani C, Biso M, Manferrari E and Mastragostino M 2008 J. Power Sources 178584

35. Arbizzani C, Biso M, Manferrari E and Mastragostino 2008 J. Power Sources 18041

36. Patra S and Munichandraiah N 2009 Langmuir 251732

37. Lefebvre M C, Qi Z and Pickup P G 1999 J. Electrochem. Soc. 1462054

38. Yang Y, Jiang Y, Xu J and Yu J 2007 Polymer 48 4459

39. Aricò A S, Creti P, Kim H, Mantegna R, Giordano N and Antonucci V 1996 J. Electrochem. Soc. 1435
40. Swathirajan S and Mikhail Y M 1992 J. Electrochem. Soc. 1392105

41. Bouzek K, Holzhauser P, Kodym R, Moravcova S and Paidar M 2007 J. Appl. Electrochem. 37137

42. Laborde H, Linger J-M and Lamy C $1994 \mathrm{~J}$. Appl. Electrochem. 24219

43. Seo S H and Lee C S 2008 Energy and Fuels 22 1204

44. Kabbabi A, Faure R, Durand R, Beden B, Hahn F, Leger J-M and Lamy C $1998 \mathrm{~J}$. Electroanal. Chem. 41444 